\title{
Absorption, Distribution, and Excretion of DJ-927, a Novel Orally Effective Taxane, in Mice, Dogs, and Monkeys
}

\author{
Chiho Ono, ${ }^{*, a}$ Atsushi TAKAO, ${ }^{b}$ and Ryo Atsumi ${ }^{a}$ \\ ${ }^{a}$ Drug Metabolism \& Physicochemical Property Research Laboratory, Daiichi Pharmaceutical Co., Ltd.; 1-16-13 Kita- \\ Kasai, Edogawa-ku, Tokyo 134-8630, Japan: and ${ }^{b}$ Daiichi Pure Chemicals Co., Ltd.; 2117 Muramatsu, Tokai, Ibaraki \\ 319-1182, Japan. Received September 24, 2003; accepted December 9, 2003; published online December 16, 2003
}

DJ-927, currently undergoing Phase I clinical trial, is a new orally effective taxane with potent antitumor effects. The absorption, tissue distribution, and excretion of DJ-927 were investigated in mice, dogs, and monkeys after a single oral administration. After oral administration of $\left[{ }^{14} \mathrm{C}\right] \mathrm{DJ}-927$, radioactivity was rapidly absorbed, with the $C_{\max }$ occurring within $1-2 \mathrm{~h}$ in all species. The blood and plasma radioactivity elimination was biphasic and species-dependent. Elimination half-life of plasma in dogs was much longer than those in monkeys or mice. In mice, radioactivity was rapidly distributed to all tissues except for the central nervous system, especially to adrenal glands, liver, pituitary glands, kidneys, lungs, and spleen. In all species, radioactivity was mainly excreted in feces. Following a single oral administration to mice, more than $80 \%$ of the radioactivity was excreted within $48 \mathrm{~h}$; in dogs and monkeys, $80 \%$ of the radioactivity was excreted within $168 \mathrm{~h}$. Urinary excretion was less than $7 \%$ of radioactive dose in all species. In vitro plasma protein binding of $\left[{ }^{14} \mathrm{C}\right] \mathrm{DJ}-927$ in the mouse, dog, and monkey plasma ranged from 92-98\%. These studies showed that, the novel oral taxane DJ-927 was rapidly absorbed in all three species when administered by the oral route. The long biological half-life and slow elimination of radioactivity were distinctive in particular, compared with commercial taxanes. DJ-927 (as parent compound and its metabolites) is widely distributed to tissues except the brain. These preclinical data are useful for the design of clinical trials of DJ-927 and also for their interpretation.

Key words DJ-927; oral taxane; pharmacokinetics; preclinical study

Taxanes are important anti-tumor drugs endowed with a unique mechanism of action: they inhibit microtubule disassembly. ${ }^{1,2)}$ The taxanes in current clinical use, paclitaxel (PTX) and docetaxel (DTX), are effective against a broad spectrum of human tumors, in particular, ovarian and breast carcinomas. ${ }^{3)}$ PTX and DTX are usually administered by i.v. infusion. However, for cancer therapy, oral administration of such cytotoxic agents is the preferred administration route because it is convenient for patients, reduces administration costs, and allows the use of more chronic treatment regimens. ${ }^{4-6)}$ Unfortunately, the bioavailability of orally administered PTX is very low, ${ }^{7,8)}$ and neither it nor orally administered DTX have shown efficacy in preclinical studies. ${ }^{9)}$ Metabolic instability and active efflux mediated by the P-glycoprotein, (P-gp) in the gut wall and liver are considered to be the major barriers to oral bioavailability. ${ }^{10,11)}$

There are a number of important mechanisms that can explain the variable and/or low bioavailability. To improve oral bioavailability, it should be considered not only physicochemical property but also affinity for drug trasnsporter and/or metabolic stability in the intestine and/or liver (first pass effect). A new, orally active taxane derivative, DJ-927 (Fig. 1), with high solubility, a better safety profile, and more potent antitumor activity against multi-drug resistant (MDR) tumors than PTX or DTX has been found. ${ }^{12)}$ In vitro DJ-927 is more cytotoxic than other taxanes against a broad range of tumor cell lines, especially against P-gp expressing cells. Additionally, orally administered DJ-927 shows potent antitumor effects against several kinds of human solid tumors that were xenografted into nude mice, against which neither PTX nor DTX was effective. ${ }^{12)}$ These profiles suggest DJ-927 is well absorbed from the gut of tumor-bearing mice. Finally, preclinical pharmacologic and toxicologic studies of DJ-927 in several animal species did not present any evidence of drug-induced neurotoxicity or cardiotoxicity. ${ }^{13)}$ In this paper, the absorption, distribution, and excretion of ${ }^{14} \mathrm{C}$-labeled DJ927 ([ ${ }^{14}$ C]DJ-927, Fig. 1) were investigated after a single oral administration to male mice to clarify the pharmacokinetic profile of DJ-927. Moreover, these studies of $\left[{ }^{14} \mathrm{C}\right] \mathrm{DJ}-927$ was investigated in two other species commonly used in toxicologic evaluations, beagle dogs and cynomolgus monkeys.

\section{MATERIALS AND METHODS}

Chemicals and Reagent DJ-927, (-)-(1S,2S,3R,4S,5R, $8 R, 9 S, 10 R, 13 S)$-4-acetoxy-2-benzoyloxy-9,10-[(1S)-2-(dimethylamino)ethylidenedioxy]-5,20-epoxy-1-hydroxytax-11en-13-yl (2R,3S)-3-(tert-butoxycarbonylamino)-3-(3-fluoro2-pyridyl)-2-hydroxypropionate was synthesized by Daiichi Pharmaceutical Co., Ltd. (Tokyo, Japan). ${ }^{14} \mathrm{C}$-labeled DJ-927 ( $\left.\left[{ }^{14} \mathrm{C}\right] \mathrm{DJ}-927\right)$ was synthesized by Daiichi Pure Chemical Co., Ltd. (DPC; Tokyo, Japan), and had a specific radioactivity of $1.76 \mathrm{GBq} / \mathrm{mmol}$. Its chemical structure and site of labeling are shown in Fig. 1. $\left[{ }^{14} \mathrm{C}\right] \mathrm{DJ}-927$ was purified by HPLC to a radiochemical purity of more than $97 \%$ just before use. Other reagents and solvents used were of analytical

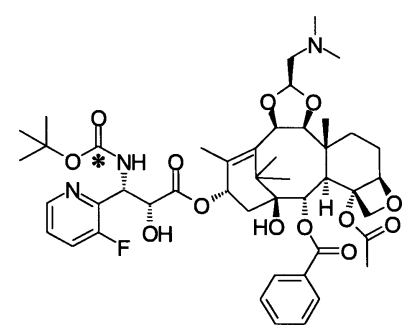

Fig. 1. Chemical Structure of DJ-927

The asterisk represents the ${ }^{14} \mathrm{C}$ labeling position. 
grade obtained commercially.

Animals Male mice were obtained from SLC Japan, Inc. (Shizuoka, Japan), and were used when they were 7 weeks old. Male beagle dogs were obtained from Toyota Tsusho Co. (Tokyo, Japan), and were used when they were $10-12$ months old. Male cynomolgus monkeys were obtained from SLC Japan, Inc., and were used when they were 3 years old. The animals fasted for about $16 \mathrm{~h}$ before administration, and feedings resumed $4 \mathrm{~h}$ after administration. All animal experiments were performed in accordance with the in-house guidelines of the Institutional Animal Care and Use Committee of DPC.

Preparation of Dosing Solutions In all studies, McIlvaine buffer solution $(0.2 \mathrm{M}$ disodium hydrogen phosphate aqueous solution, $0.1 \mathrm{M}$ citric acid aqueous solution, $\mathrm{pH} 4.0$ ) was used as the vehicle for the dosing solution. $\left[{ }^{14} \mathrm{C}\right] \mathrm{DJ}-927$ ethanol solution was taken and evaporated to dryness under a stream of nitrogen gas. The residue was dissolved in the vehicle to prepare the dosing solution. Solutions of $\left[{ }^{14} \mathrm{C}\right] \mathrm{DJ}-$ 927 were prepared at concentrations of $0.4 \mathrm{mg} / \mathrm{ml}$ for mice, $0.6 \mathrm{mg} / \mathrm{ml}$ for dogs, and $0.5 \mathrm{mg} / \mathrm{ml}$ for monkeys.

Absorption and Excretion Study in Mice $\left[{ }^{14} \mathrm{C}\right] \mathrm{DJ}-927$ was orally administered at a dose of $4 \mathrm{mg} / \mathrm{kg}$ to male mice for a single-dose pharmacokinetic and excretion study. Blood samples were collected from the inferior vena cava of mice under ether anesthesia at $0.5,1,2,4,8,12,24,48,72,96$, 120,144 , and $168 \mathrm{~h}$ after administration into heparinized microtubes. A portion of each blood sample was used for direct measurement of radioactivity, and plasma samples were obtained by centrifugation of each remaining sample at $8000 \boldsymbol{g}$ for $5 \mathrm{~min}$ at $4{ }^{\circ} \mathrm{C}$. For the excretion studies, three mice were individually housed in metabolic cages after single oral administration. Samples of urine and feces samples were collected during the following periods up to $168 \mathrm{~h}$ after dosing: $0-4,4-8,8-24$, and every $24 \mathrm{~h}$ thereafter for urine; and $0-24$ and every $24 \mathrm{~h}$ thereafter for feces. The fecal samples were homogenized with distilled water. After sample collection, an overdose of diethylether was used to sacrifice the animals. The carcasses were placed in $200 \mathrm{ml}$ of $0.5 \mathrm{~N}$ sodium hydroxide and $30 \mathrm{ml}$ of toluene and then homogenized with water. All samples were stored at $-20^{\circ} \mathrm{C}$ until analyzed.

Absorption and Excretion Study in Dogs $\left[{ }^{14} \mathrm{C}\right] \mathrm{DJ}-927$ was orally administered at a dose of $0.6 \mathrm{mg} / \mathrm{kg}$ to male dogs for the single-dose pharmacokinetic and excretion study. Blood samples were collected from the abdominal aorta at $0.250 .5,1,2,4,8,12,24,48,72,96,120,144,168 \mathrm{~h}$, and every $24 \mathrm{~h}$ periods up to $336 \mathrm{~h}$ after administration into a vacuum tube containing heparin. A portion of each blood sample was used for direct measurement of radioactivity, and plasma samples were obtained by centrifugation of each remaining sample at $1800 \mathrm{~g}$ for $15 \mathrm{~min}$ at $4{ }^{\circ} \mathrm{C}$. For the excretion studies, three dogs were individually housed in metabolic cages after single oral administration. Samples of urine and feces were collected during the following periods up to $336 \mathrm{~h}$ after dosing: $0-4,4-8,8-24$ and every $24 \mathrm{~h}$ thereafter for urine; and $0-8,8-24$, and every $24 \mathrm{~h}$ thereafter for feces. The fecal samples were homogenized with distilled water. After sample collection, each dog was sacrificed by exsanguination from the abdominal aorta while under anesthesia induced by an intramuscular administration of ketamine hydroxide and xylazine hydroxide mixture. Tissues were collected from animal at the last time point $(336 \mathrm{~h})$ to determine the concentration and distribution of radioactivity in the tissues and to calculate the residual radioactivity in carcasses. The metabolic cages were washed with water, and radioactivity in washings was also determined.

Absorption and Excretion Study in Monkeys $\left[{ }^{14} \mathrm{C}\right] \mathrm{DJ}-$ 927 was orally administered at a dose of $1 \mathrm{mg} / \mathrm{kg}$ to male monkeys for a single-dose pharmacokinetic and excretion study. Blood samples were collected from the abdominal aorta at $0.250 .5,1,2,4,8,12,24,48,72,96,120,144$, $168 \mathrm{~h}$, and every $24 \mathrm{~h}$ periods up to $336 \mathrm{~h}$ after administration into a vacuum tube containing heparin. A portion of each blood sample was used for direct measurement of radioactivity, and plasma samples were obtained by centrifugation of each remaining sample at $1800 \mathrm{~g}$ for $15 \mathrm{~min}$ at $4{ }^{\circ} \mathrm{C}$. For the excretion studies, the monkeys were individually housed in metabolic cages after single oral administration. Samples of urine and feces were collected during following periods up to 336 h after dosing: $0-4,4-8,8-24$, and every $24 \mathrm{~h}$ thereafter for urine, and $0-8,8-24$, and every $24 \mathrm{~h}$ thereafter for feces. The fecal samples were homogenized with distilled water. After sample collection, each monkey was sacrificed by exsanguinations from the abdominal aorta while under anesthesia induced by an intramuscular administration of a ketamine hydroxide. Tissues were collected at the last time point $(336 \mathrm{~h})$ to determine the concentration and distribution of radioactivity in the tissues and to calculate the residual radioactivity in carcasses. The metabolic cages were washed with water, and radioactivity in washings was also determined.

Tissue Distribution Study in Mice After oral administration of $\left[{ }^{14} \mathrm{C}\right] \mathrm{DJ}-927$ to male mice at dose of $4 \mathrm{mg} / \mathrm{kg}$, mice for each time point were anesthetized with ether and bleeding from the inferior vena cava $1,8,24,72$, and $168 \mathrm{~h}$ after administration. Immediately after blood collection, the tissues and organs indicated in Table 2 were removed and the wet mass of each was measured. The liver, small intestine, and large intestine were homogenized in a 2 -fold volume $(\mathrm{w} / \mathrm{v})$ of saline. The other samples and homogenates described above were dissolved in $2 \mathrm{ml}$ of the tissue solubilizer Soluene$350^{\mathrm{TM}}$ while heating. The concentration and percentage distribution of radioactivity in these tissues and tissue homogenates were then determined.

In Vitro Distribution to Blood Cells and Plasma Protein Binding The partitioning of DJ-927 into erythrocytes was determined by incubating the radiolabeled compound with fresh, heparin-treated whole blood from mice, dogs, or monkeys. $\left[{ }^{14} \mathrm{C}\right] \mathrm{DJ}-927$ was added to blood from each animal to yield three concentrations of 25,50 , and $500 \mathrm{ng} / \mathrm{ml}$, and the samples were incubated at $37^{\circ} \mathrm{C}$ for $5 \mathrm{~min}$. Plasma was separated by centrifugation $\left(8000 \mathrm{~g}, 4^{\circ} \mathrm{C}, 5 \mathrm{~min}\right)$, and aliquots were taken for scintillation counting. The ratio of the radioactivity in erythrocytes to that in blood (RBC) was calculated from the following equation:

$\operatorname{RBC}(\%)=\left[1-\left(1-H_{\mathrm{t}}\right) / R_{\mathrm{b}}\right] \times 100$

where $H_{\mathrm{t}}$ is the hematocrit and $R_{\mathrm{b}}$ is the ratio of the blood to the plasma concentration.

The binding of DJ-927 to plasma protein was determined by incubating the compound with pooled plasma from mice, dogs, and monkeys in the concentration range of $0.1-$ 
$10 \mu \mathrm{g} / \mathrm{ml}$. $\left[{ }^{14} \mathrm{C}\right] \mathrm{DJ}-927$ was added to plasma samples and incubated for $15 \mathrm{~min}$ at $37^{\circ} \mathrm{C}$. An aliquot of each sample was taken to determine total radioactivity (concentration of radioactivity in plasma, $C_{\mathrm{p}}$ ). Another aliquot of each sample was transferred to $0.23 \mathrm{PC}$ tubes and centrifuged at $200000 \mathrm{~g}$ for $16 \mathrm{~h}$ at $4{ }^{\circ} \mathrm{C}$. An aliquot of each supernatant (concentration of radioactivity in the unbound fraction, $C_{\mathrm{f}}$ ) was taken for scintillation counting. The ratio of protein binding was calculated from the following equation:

protein binding ratio $(\%)=\left(1-C_{\mathrm{f}} / C_{\mathrm{p}}\right) \times 100$

Determination of Radioactivity in the Samples Radioactivity in the samples was measured using an LSC (2700TR, Packard; Meriden, CT, U.S.A.). The radioactivity of samples in glass vials was measured, and radioactivity (dpm) was counted for $2 \mathrm{~min}$ after addition of a scintillator. The counting efficiency was automatically corrected using an external standard. Samples from control animals treated by the same methods were used to obtain background counts. The radioactivity detection limit was defined as twice the value of the corresponding background count. The radioactive concentration in blood, plasma, and each tissue sample was calculated as the equivalent concentration of $\left[{ }^{14} \mathrm{C}\right] \mathrm{DJ}-$ 927 from the specific radioactivity of each dosing solution. The excreted radioactivity in urine and feces is expressed as a percentage of the administered radioactivity.

Pharmacokinetic Calculations A noncompartmental methods was used to determine the pharmacokinetics of DJ927. The maximum plasma and blood concentration $\left(C_{\max }\right)$ and the time $\left(t_{\max }\right)$ to reach this value were determined from the observed highest concentration and the time of its occurrence, respectively. The concentrations of radioactivity in plasma and blood were converted to logarithms and plotted against time. TOPFIT computer software (ver. 2, Gustav Fischer Verlag, Stuttgart, Germany) was used to calculate the terminal elimination half-life $\left(t_{1 / 2}\right)$ and the area under the concentration-time curve $(A U C)$ for plasma and blood.

\section{RESULTS}

Blood and Plasma Radioactivity Concentration-Time Profiles in Mice, Dogs, and Monkeys Mean plasma and blood levels of radioactivity after a single oral administration of $\left[{ }^{14} \mathrm{C}\right] \mathrm{DJ}-927$ to male mice, dogs, and monkeys are shown in Fig. 2 and the pharmacokinetic parameters are shown in Table 1. After a single oral administration of $\left[{ }^{14} \mathrm{C}\right] \mathrm{DJ}-927$ to male mice at a dose of $4 \mathrm{mg} / \mathrm{kg}$, the radioactive concentration of in plasma (mean of three mice at each time point) was a maximum $\left(C_{\max }\right)$ of $545.0 \mathrm{ng}$ eq. $/ \mathrm{ml}$ at $2 \mathrm{~h}$, and then declined
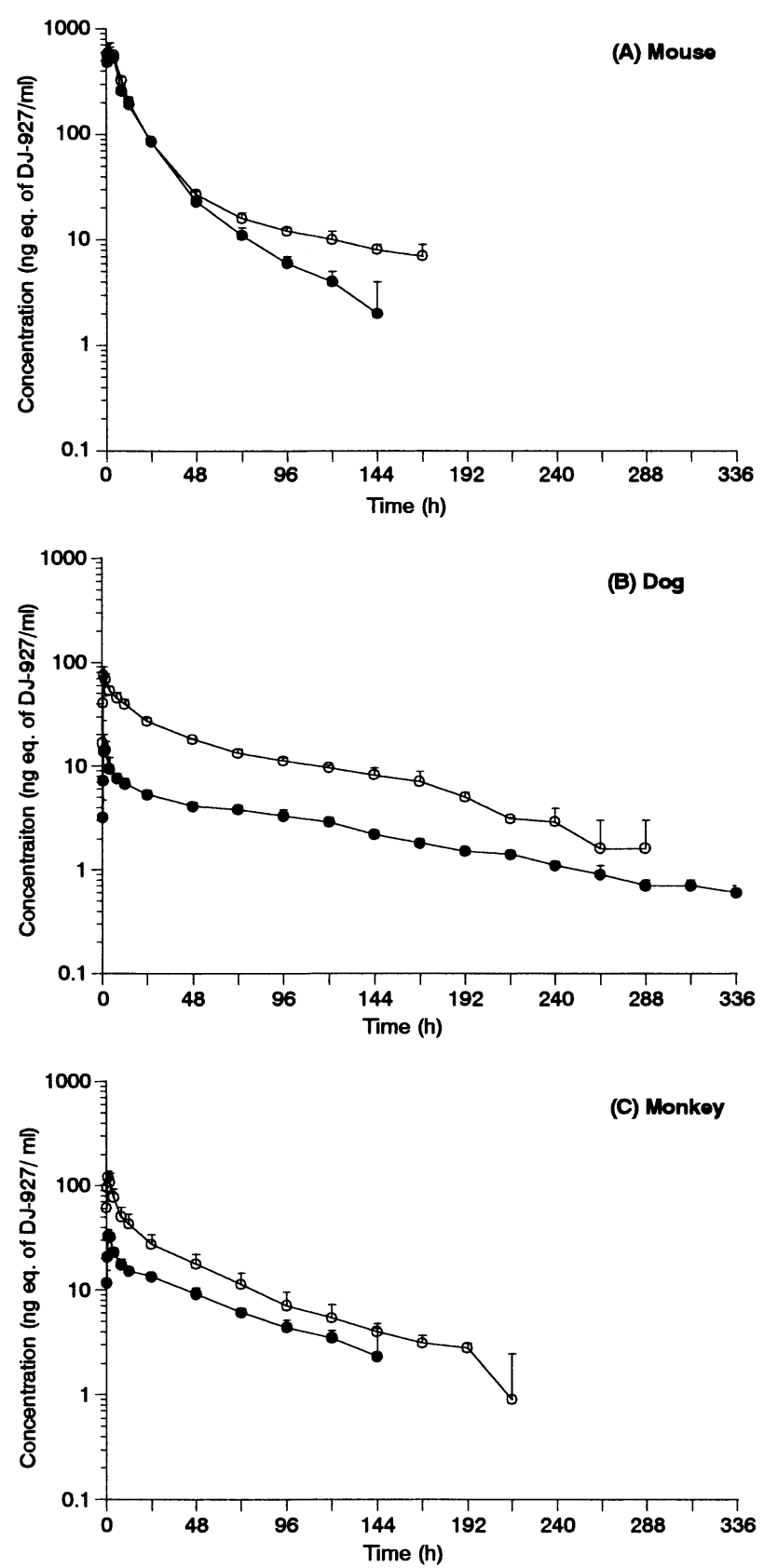

Fig. 2. Mean Blood $(\bigcirc)$ and Plasma (O) Levels of Radioactivity after a Single Oral Administration of $\left[{ }^{14} \mathrm{C}\right] \mathrm{DJ}-927$ to Male Mice at a Dose of $4 \mathrm{mg} / \mathrm{kg}$ (A), to Male Dogs at a Dose of $0.6 \mathrm{mg} / \mathrm{kg}$ (B) and to Male Monkeys at a Dose of $1 \mathrm{mg} / \mathrm{kg}(\mathrm{C})$

Each point with bar represents the mean \pm S.D. from three animals.

Table 1. Pharmacokinetic Parameters of $\left[{ }^{14} \mathrm{C}\right] \mathrm{DJ}-927$ in Blood and Plasma after a Single Oral Administration of $\left[{ }^{14} \mathrm{C}\right] \mathrm{DJ}-927$ at Dose of $4 \mathrm{mg} / \mathrm{kg}$ to Mice, $0.6 \mathrm{mg} / \mathrm{kg}$ to Dogs, and $1 \mathrm{mg} / \mathrm{kg}$ to Monkeys

\begin{tabular}{|c|c|c|c|c|c|c|}
\hline \multirow{2}{*}{ PK parameters } & \multicolumn{2}{|c|}{ Mouse } & \multicolumn{2}{|c|}{ Dog } & \multicolumn{2}{|c|}{ Monkey } \\
\hline & $\operatorname{Blood}^{a}$ & Plasma $^{a}$ ) & Blood & Plasma & Blood & Plasma \\
\hline$t_{\max }(\mathrm{h})$ & 1 & 2 & $1.0 \pm 0.0$ & $2.0 \pm 1.0$ & $1.0 \pm 0.0$ & $2.0 \pm 1.0$ \\
\hline$C_{\max }($ ng eq. $/ \mathrm{ml})$ & 581.0 & 545.0 & $75.0 \pm 14.6$ & $15.4 \pm 4.8$ & $120.1 \pm 18.0$ & $34.7 \pm 3.8$ \\
\hline$t_{1 / 2}(\mathrm{~d})$ & 2.7 & 1.2 & $3.0 \pm 0.4$ & $4.0 \pm 0.4$ & $2.1 \pm 0.1$ & $2.2 \pm 0.4$ \\
\hline$A U C_{0-\infty}(\mu \mathrm{g}$ eq. $\cdot \mathrm{h} / \mathrm{ml})$ & 10.1 & 8.3 & $3.5 \pm 0.09$ & $0.9 \pm 0.05$ & $3.0 \pm 0.7$ & $1.4 \pm 0.2$ \\
\hline
\end{tabular}

Each value represents the mean \pm S.D. $(n=3)$. a) PK parameters were calculated from the mean values of concentration at each time point. 
Table 2. Cumulative Excretion of Radioactivity in Urine and Feces after a Single Oral Administration of $\left[{ }^{14} \mathrm{C}\right] \mathrm{DJ}-927$ at a Dose of $4 \mathrm{mg} / \mathrm{kg}$ to Mice, $0.6 \mathrm{mg} / \mathrm{kg}$ to Dogs, and $1 \mathrm{mg} / \mathrm{kg}$ to Monkeys

\begin{tabular}{|c|c|c|c|c|c|c|}
\hline \multirow{3}{*}{ Time period $(\mathrm{h})$} & \multicolumn{6}{|c|}{$\%$ of administered dose } \\
\hline & \multicolumn{2}{|c|}{ Mouse } & \multicolumn{2}{|c|}{ Dog } & \multicolumn{2}{|c|}{ Monkey } \\
\hline & Urine & Feces & Urine & Feces & Urine & Feces \\
\hline $0-4$ & $0.4 \pm 0.3$ & $ـ^{a)}$ & $0.1 \pm 0.2$ & $\ldots$ & $1.4 \pm 1.4$ & -a) \\
\hline $0-8$ & $2.2 \pm 0.7$ & $\ldots^{a)}$ & $0.1 \pm 0.2$ & $0.0 \pm 0.0$ & $2.1 \pm 1.5$ & $0.0 \pm 0.0$ \\
\hline $0-24$ & $5.1 \pm 0.7$ & $68.0 \pm 3.8$ & $1.4 \pm 0.3$ & $28.5 \pm 6.3$ & $3.1 \pm 1.6$ & $6.5 \pm 7.8$ \\
\hline $0-48$ & $5.9 \pm 0.9$ & $86.1 \pm 2.9$ & $2.3 \pm 0.3$ & $46.6 \pm 3.8$ & $3.9 \pm 1.6$ & $32.0 \pm 25.7$ \\
\hline $0-72$ & $6.1 \pm 1.0$ & $89.7 \pm 3.2$ & $2.9 \pm 0.3$ & $60.5 \pm 3.5$ & $4.3 \pm 1.6$ & $62.5 \pm 16.4$ \\
\hline $0-96$ & $6.2 \pm 1.0$ & $90.9 \pm 3.1$ & $3.4 \pm 0.3$ & $68.8 \pm 1.4$ & $4.6 \pm 1.6$ & $78.4 \pm 7.4$ \\
\hline $0-120$ & $6.3 \pm 1.0$ & $91.6 \pm 3.1$ & $3.7 \pm 0.3$ & $75.3 \pm 2.3$ & $4.8 \pm 1.6$ & $84.2 \pm 4.9$ \\
\hline $0-144$ & $6.4 \pm 1.2$ & $92.2 \pm 3.0$ & $4.1 \pm 0.3$ & $78.8 \pm 1.4$ & $4.9 \pm 1.6$ & $87.4 \pm 4.2$ \\
\hline $0-168$ & $6.4 \pm 1.1$ & $92.5 \pm 2.9$ & $4.3 \pm 0.3$ & $83.0 \pm 1.0$ & $5.0 \pm 1.6$ & $89.2 \pm 4.1$ \\
\hline $0-192$ & & & $4.4 \pm 0.3$ & $85.3 \pm 0.9$ & $5.0 \pm 1.5$ & $90.1 \pm 3.9$ \\
\hline $0-216$ & & & $4.6 \pm 0.3$ & $86.7 \pm 1.1$ & $5.0 \pm 1.5$ & $90.7 \pm 3.8$ \\
\hline $0-240$ & & & $4.7 \pm 0.3$ & $88.0 \pm 0.6$ & $5.1 \pm 1.6$ & $91.0 \pm 3.8$ \\
\hline $0-264$ & & & $4.8 \pm 0.3$ & $89.4 \pm 0.3$ & $5.1 \pm 1.6$ & $91.3 \pm 3.7$ \\
\hline $0-288$ & & & $4.8 \pm 0.3$ & $90.2 \pm 0.3$ & $5.1 \pm 1.5$ & $91.4 \pm 3.7$ \\
\hline $0-312$ & & & $4.9 \pm 0.2$ & $90.7 \pm 0.3$ & $5.1 \pm 1.5$ & $91.5 \pm 3.7$ \\
\hline $0-336$ & & & $4.9 \pm 0.2$ & $91.3 \pm 0.4$ & $5.1 \pm 1.5$ & $91.6 \pm 3.7$ \\
\hline
\end{tabular}

Each value represents the mean \pm S.D. $(n=3) . \quad a)$ Not collected.

biphasically with a terminal biologic half-life $\left(t_{1 / 2}\right)$ of $1.2 \mathrm{~d}$ (Fig. 2A, Table 1). The radioactive concentration in whole blood was similar to the level in plasma, and disappeared biphasically with $t_{1 / 2}$ of $2.7 \mathrm{~d}$. The $A U C_{0-\infty}$ values for plasma and blood were 8.3 and $10.1 \mu \mathrm{g}$ eq. $\cdot \mathrm{h} / \mathrm{ml}$, respectively. After a single oral administration of $\left[{ }^{14} \mathrm{C}\right] \mathrm{DJ}-927$ to male dogs at a dose of $0.6 \mathrm{mg} / \mathrm{kg}$, the radioactive concentration in plasma (mean of three dogs) was a $C_{\max }$ of $15.4 \mathrm{ng}$ eq. $/ \mathrm{ml}$ at $2 \mathrm{~h}$ and disappeared biphasically with $t_{1 / 2}$ of $4.0 \mathrm{~d}$ (Fig. 2B, Table 1). The plasma $A U C_{0-\infty}$ was $0.9 \mu \mathrm{g}$ eq. $\cdot \mathrm{h} / \mathrm{ml}$. The radioactive concentration in blood was much higher than that in plasma. The blood $A U C_{0-\infty}$ was $3.5 \mu \mathrm{g}$ eq. $\cdot \mathrm{h} / \mathrm{ml}$. The calculated RBC values were $76.9 \%$ to $91.3 \%$ up to $288 \mathrm{~h}$ after administration (data not shown). After a single oral administration of $\left[{ }^{14} \mathrm{C}\right] \mathrm{DJ}-927$ to male monkeys at a dose of $1 \mathrm{mg} / \mathrm{kg}$, the radioactive concentration in the plasma (mean of three monkeys) reached a $C_{\max }(34.7 \mathrm{ng}$ eq. $/ \mathrm{ml})$ at $2 \mathrm{~h}$ after administration (Fig. 2C, Table 1). The $t_{1 / 2}$ was $2.2 \mathrm{~d}$. The plasma $A U C_{0-\infty}$ was $1.4 \mu \mathrm{g}$ eq. $\cdot \mathrm{h} / \mathrm{ml}$. The $C_{\max }(120.1 \mathrm{ng}$ eq. $/ \mathrm{ml})$ of blood at $1 \mathrm{~h}$ after administration was about 4 -fold higher than that of plasma. The blood $A U C_{0-\infty}$ was $3.0 \mu \mathrm{g}$ eq. $\cdot \mathrm{h} / \mathrm{ml}$. The calculated RBC values were $50.5 \%$ to $88.3 \%$ by $144 \mathrm{~h}$ after administration (data not shown).

Excretion in Mice, Dogs, and Monkeys Cumulative excretions of radioactivity in urine and feces of mice, dogs, and monkeys after a single oral administration of $\left[{ }^{14} \mathrm{C}\right] \mathrm{DJ}-927$ are shown in Table 2 . In mice, the radioactivity was mainly excreted in feces, of which $68.0 \pm 3.8 \%$ (mean \pm S.D., $n=3$ ) of the administered amount $(4 \mathrm{mg} / \mathrm{kg})$ was excreted during the initial $24 \mathrm{~h}$ after administration and $92.5 \pm 2.9 \%$ was excreted by $168 \mathrm{~h}$ after administration. The urinary excretion was very low, only $6.4 \%$ up to $168 \mathrm{~h}$ after administration. The excretion of radioactivity in the expired air was $1.3 \%$ by $48 \mathrm{~h}$, and then no radioactivity was excreted in expired air (data not shown). The radioactivity remaining in the carcass was $0.6 \%$ at $168 \mathrm{~h}$ after administration. The total excretion of radioactivity in the excreta was $100.1 \%$ at $168 \mathrm{~h}$ after administration.
In contrast, the radioactivity excreted in the feces of dogs was $28.5 \pm 6.3 \%$, and in the urine was $1.4 \pm 0.3 \%$ over the first $24 \mathrm{~h}$ after administration $(0.6 \mathrm{mg} / \mathrm{kg})$. Over $336 \mathrm{~h}, 91.3 \pm$ $0.4 \%$ of the administered dose was excreted in feces and $4.9 \pm 0.2 \%$ of the administered dose excreted in urine. The total amount of radioactivity excreted was $96.2 \pm 0.4 \%$ of the administered dose at $336 \mathrm{~h}$, and the radioactivity. As in mice, fecal excretion was also the main route, but dogs excreted radioactivity more slowly than mice did. The percentages of radioactivity distributed in the liver, skin, skeletal muscles, fat, bile in the gall bladder, and gastro-intestinal contents ranged from 0.1 to $0.8 \%$ of the administered dose at the end of the study period (data not shown). In monkeys, the amount of radioactivity excreted in the feces was $6.5 \pm 7.8 \%$ of the administered dose and in the urine was $3.1 \pm 1.6 \%$ over the first $24 \mathrm{~h}$ after administration $(1 \mathrm{mg} / \mathrm{kg})$. A total of $96.7 \pm 2.6 \%$ administered dose was recovered in the excreta, of which $91.6 \pm 3.7 \%$ was in the feces and $5.1 \pm 1.5 \%$ was in the urine, by $336 \mathrm{~h}$ after administration. The percentages of radioactivity distributed in the skeletal muscles, liver, and gastro-intestinal contents were $0.1-0.2 \%$ of the administered dose at the end of the study period (data not shown). Fecal excretion was also the main route, as previously described for mice and dogs; moreover, the rate of excretion in monkeys was slower than the rate in mice, but not as slow as rate in dogs.

Tissue Distribution in Mice The concentration of radioactivity in tissues after a single oral administration of $\left[{ }^{14} \mathrm{C}\right] \mathrm{DJ}-927$ to mice is shown in Table 3 . The radioactivity in all the tissues except for the brain was higher than in plasma at $1 \mathrm{~h}$ after administration. Most tissues showed their highest concentration at $1 \mathrm{~h}$ after administration, indicating that $\left[{ }^{14} \mathrm{C}\right] \mathrm{DJ}-927$ rapidly distributes to tissues. The highest concentration of radioactivity was observed in the adrenal glands (11410 ng eq./g), followed by the liver (11269 ng eq./g), pituitary gland (10431 ng eq./g), kidneys (9324 ng eq./g), and lungs $(8762 \mathrm{ng}$ eq. $/ \mathrm{g})$ at $1 \mathrm{~h}$ after oral administration. Approximately $99 \%$ of the radioactivity was eliminated by $168 \mathrm{~h}$ 
Table 3. Tissue Distribution of Radioactivity after a Single Oral Administration of $\left[{ }^{14} \mathrm{C}\right] \mathrm{DJ}-927 \mathrm{to} \mathrm{Mice}$ at a Dose of $4 \mathrm{mg} / \mathrm{kg}$

\begin{tabular}{|c|c|c|c|c|c|}
\hline \multirow{2}{*}{ Tissue } & \multicolumn{5}{|c|}{ Radioactivity concentration (ng eq. of DJ-927/g or ml) } \\
\hline & $1 \mathrm{~h}$ & $8 \mathrm{~h}$ & $24 \mathrm{~h}$ & $72 \mathrm{~h}$ & $168 \mathrm{~h}$ \\
\hline Plasma & $455 \pm 161$ & $268 \pm 30$ & $79 \pm 12$ & $11 \pm 0$ & $1 \pm 1$ \\
\hline Blood & $491 \pm 126$ & $309 \pm 20$ & $76 \pm 7$ & $19 \pm 2$ & $9 \pm 0$ \\
\hline Cerebrum & $54 \pm 24$ & $104 \pm 9$ & $81 \pm 21$ & $40 \pm 2$ & $22 \pm 3$ \\
\hline Cerebellum & $86 \pm 40$ & $121 \pm 33$ & $74 \pm 13$ & $24 \pm 2$ & $9 \pm 2$ \\
\hline Pituitary gland ${ }^{a)}$ & 10431 & 15980 & 3490 & 169 & 0 \\
\hline Eyeball & $462 \pm 220$ & $842 \pm 100$ & $467 \pm 95$ & $122 \pm 1$ & $25 \pm 2$ \\
\hline Harderian gland & $3564 \pm 1708$ & $4388 \pm 270$ & $713 \pm 127$ & $49 \pm 6$ & $3 \pm 5$ \\
\hline Thyroid gland $^{a)}$ & 5341 & 4750 & 564 & 91 & 46 \\
\hline Mandibular gland & $4914 \pm 2322$ & $5122 \pm 363$ & $932 \pm 134$ & $67 \pm 3$ & $14 \pm 2$ \\
\hline Mandibular lymph node & $3143 \pm 2164$ & $3730 \pm 483$ & $399 \pm 65$ & $0 \pm 0$ & $0 \pm 0$ \\
\hline Thymus & $1563 \pm 838$ & $3611 \pm 575$ & $1337 \pm 405$ & $37 \pm 6$ & $3 \pm 6$ \\
\hline Heart & $3558 \pm 861$ & $1879 \pm 27$ & $211 \pm 21$ & $25 \pm 2$ & $7 \pm 3$ \\
\hline Lung & $8762 \pm 2223$ & $4761 \pm 60$ & $612 \pm 50$ & $71 \pm 5$ & $19 \pm 2$ \\
\hline Liver & $11269 \pm 2006$ & $10482 \pm 348$ & $4940 \pm 498$ & $1188 \pm 57$ & $250 \pm 30$ \\
\hline Kidney & $9324 \pm 3203$ & $5663 \pm 282$ & $831 \pm 158$ & $66 \pm 3$ & $20 \pm 2$ \\
\hline Adrenal gland ${ }^{a)}$ & 11410 & 3694 & 511 & 73 & 0 \\
\hline Spleen & $8060 \pm 2787$ & $6243 \pm 693$ & $601 \pm 91$ & $47 \pm 4$ & $12 \pm 3$ \\
\hline Pancreas & $4807 \pm 2233$ & $3501 \pm 46$ & $717 \pm 118$ & $48 \pm 3$ & $10 \pm 1$ \\
\hline Fat & $4935 \pm 2477$ & $1647 \pm 222$ & $162 \pm 25$ & $12 \pm 1$ & $6 \pm 1$ \\
\hline Skeletal muscle & $1199 \pm 548$ & $946 \pm 39$ & $132 \pm 17$ & $13 \pm 1$ & $5 \pm 1$ \\
\hline Skin & $733 \pm 291$ & $1038 \pm 172$ & $284 \pm 48$ & $17 \pm 4$ & $6 \pm 1$ \\
\hline Bone marrow $^{a}$ ) & 4765 & 10016 & 890 & 51 & 0 \\
\hline Aorta $^{a)}$ & 4584 & 3539 & 490 & 30 & 0 \\
\hline Testis & $85 \pm 50$ & $336 \pm 56$ & $392 \pm 162$ & $146 \pm 14$ & $44 \pm 4$ \\
\hline Epididymis & $552 \pm 267$ & $1534 \pm 237$ & $734 \pm 124$ & $127 \pm 23$ & $31 \pm 3$ \\
\hline Prostate gland ${ }^{a)}$ & 1171 & 1879 & 866 & 89 & 10 \\
\hline Stomach & $3246 \pm 340$ & $2233 \pm 311$ & $512 \pm 37$ & $41 \pm 5$ & $13 \pm 3$ \\
\hline Small intestine & $5878 \pm 957$ & $3557 \pm 662$ & $682 \pm 103$ & $31 \pm 3$ & $14 \pm 5$ \\
\hline Large intestine & $1429 \pm 771$ & $3268 \pm 824$ & $726 \pm 40$ & $34 \pm 4$ & $13 \pm 5$ \\
\hline Urinary bladder & $1250 \pm 846$ & $2363 \pm 571$ & $685 \pm 33$ & $45 \pm 17$ & $3 \pm 5$ \\
\hline
\end{tabular}

Each value represents the mean \pm S.D. $(n=3) . \quad$ a) Pooled samples of three animals.

Table 4. In Vitro Distribution to Blood Cells Varying Concentrations of $\left[{ }^{14} \mathrm{C}\right]-\mathrm{DJ}-927$ in Mouse, Dog, and Monkey Blood

\begin{tabular}{|c|c|c|c|}
\hline \multirow{2}{*}{$\begin{array}{l}\text { Concentration } \\
(\mathrm{ng} / \mathrm{ml})\end{array}$} & \multicolumn{3}{|c|}{$\mathrm{RBC}(\%)$} \\
\hline & Mouse & Dog & Monkey \\
\hline 25 & $53.1 \pm 1.7$ & $86.3 \pm 3.3$ & $77.0 \pm 2.9$ \\
\hline 50 & $\ldots^{a)}$ & $87.3 \pm 3.9$ & $76.8 \pm 3.5$ \\
\hline 500 & $52.9 \pm 0.5$ & $\ldots^{a)}$ & _a) \\
\hline Mean $^{b)}$ & 53.0 & 86.8 & 76.9 \\
\hline
\end{tabular}

Each value represents the mean \pm S.D. of three experiments. a) Not determined. $b$ ) Each value represents the mean of two concentrations.

after dosing. Similar tissue distribution patterns were found in whole body autoradiography (data not shown).

In Vitro Distribution to Blood Cells and Plasma Protein Binding In vitro, the distribution of radioactivity into erythrocytes (RBC) were $53.0 \%, 86.8 \%$, and $76.9 \%$ in mice, dogs, and monkeys in a three concentration range of 25, 50, and $500 \mathrm{ng} / \mathrm{ml}$ (Table 4). RBC for dogs was higher than the value for mice and monkeys, which was consistent with in vivo results for these animals. This binding was reversible.

The plasma protein binding of $\left[{ }^{14} \mathrm{C}\right] \mathrm{DJ}-927$ was similar in the three species studied, with mean percent bound values in mice, dogs, and monkeys plasma were $98.0 \%, 95.0 \%$, and $92.5 \%$, respectively (Table 5). $\left[{ }^{14} \mathrm{C}\right] \mathrm{DJ}-927$ was highly bound to plasma proteins but concentration independently over the concentration range from 0.1 to $10 \mu \mathrm{g} / \mathrm{ml}$.
Table 5. In Vitro Protein Binding Varying Concentrations of $\left[{ }^{14} \mathrm{C}\right]-\mathrm{DJ}-927$ in Mouse, Dog, and Monkey Plasma

\begin{tabular}{cccc}
\hline \hline \multirow{2}{*}{$\begin{array}{c}\text { Concentration } \\
(\mu \mathrm{g} / \mathrm{ml})\end{array}$} & \multicolumn{3}{c}{ Protein binding ratio (\%) } \\
\cline { 2 - 4 } & Mouse & Dog & Monkey \\
\hline 0.1 & $97.8 \pm 0.22$ & $94.9 \pm 0.46$ & $91.8 \pm 0.24$ \\
1 & $98.5 \pm 0.23$ & $95.1 \pm 0.25$ & $92.9 \pm 0.2$ \\
5 & $98.1 \pm 0.12$ & $95.1 \pm 0.09$ & $92.5 \pm 0.04$ \\
10 & $97.4 \pm 0.04$ & $94.8 \pm 0.27$ & $92.7 \pm 0.06$ \\
Mean \pm S.D. $^{a)}$ & $98.0 \pm 0.35$ & $95.0 \pm 0.12$ & $92.5 \pm 0.56$ \\
\hline
\end{tabular}

Each value represents the mean \pm S.D. of three experiments. a) Each value represents the mean \pm S.D. of four concentrations.

\section{DISCUSSION}

The taxanes, PTX and DTX are widely used hydrophobic antineoplastic agents that demonstrate significant antitumor activity against a broad spectrum of human tumors such as refractory ovarian, breast, and non-small-cell lung carcinomas. ${ }^{3,14)}$ Unfortunately, neither agent can be used orally, because of low oral bioavailability. ${ }^{7-9)}$ The poor absorption characteristics of PTX appear to be related to the presence of the P-glycoprotein (P-gp) drug efflux transport protein in intestinal cells, ${ }^{8,10,15)}$ since the systemic exposure of orally administered PTX in mice is significantly enhanced by coadministration of a P-gp blocker such as PSC833 or cyclosporin A. ${ }^{16,17)}$ However, in regard to DTX, it is suggested that efficient first-pass metabolism in gut and liver, probably 
by CYP3A enzymes in mice, is the most important factor determining its low bioavailability. ${ }^{18)}$

$\mathrm{P}$-gp is an energy-dependent multi-drug efflux pump that was initially discovered by its ability to confer multidrug resistance (MDR). ${ }^{19)} \mathrm{P}$-gp is found not only tumor cells but also in healthy tissues and organs such as kidneys, liver adrenal glands, and intestines, where it is predominantly located on the apical side of epithelial cells. ${ }^{20,21)}$ Recently, many reports have shown that $\mathrm{P}$-gp is involved in intestinal absorption of drugs. ${ }^{22}$ ) On the other hand, CYP is the main oxidative drug metabolizing enzyme system. Especially, CYP3A subfamily is the predominant drug metabolizing enzymes and accounts for approximately $30 \%$ of hepatic CYP and more than $70 \%$ of intestinal CYP expression. ${ }^{23)}$ CYP $3 \mathrm{~A}$ is responsible for significant first-pass metabolism of orally administered drugs. It is reported that many substrates for Pgp and CYP3A are overlapping and both proteins are responsible for the poor bioavailability observed for many orally administered drugs. ${ }^{22,23)}$ These observations suggest that oral cytotoxic agents would be natural targets of this elimination system, and that drugs designed to elude capture by this system would have better bioavailability. In our preliminary studies, oral bioavailability of DJ-927 was $107 \%$ in mice, $47 \%$ in dogs, and $63 \%$ in monkeys after intravenous and oral administration of non-labeled DJ-927. ${ }^{24)}$ The bioavailability of DJ-927 exhibits a species difference. Several PK studies indicate that DJ-927 is highly permeable in gut lumen. Dogs are considered to have extensive first-pass metabolism (unpublished data). In addition, in vitro study using human liver microsome revealed that metabolic rate of DJ-927 is slow and that CYP 3A family is the responsible enzyme for its metabolism. ${ }^{24)}$ Intrinsic clearance $\left(V_{\max } / K_{\mathrm{m}, \mathrm{app}}\right)$ of DJ-927 major metabolite was scaled up to predict the human clearance. The human clearance is estimated to be very low. In pharmacologic studies, DJ-927 is more effective than PTX and DTX against P-gp-expressing cells lines. ${ }^{12)}$ These results suggest that DJ-927 is a poor substrate for P-gp and CYP3A and that it escapes biological barriers in the gut and liver.

Other factors for low bioavailability are considered physicochemical properties such as solubility, $\mathrm{p} K_{\mathrm{a}}$ of compound. PTX has very poor solubility in water, therefore, the commercial injection formulation consists of a sterile solution of the drug in Cremophor EL and hydrated alcohol to dissolve PTX. $^{25)}$ Cremophor EL brings a number of pharmacologic, pharmacokinetic, and pharmaceutic drawbacks such as hypersensitivity reactions, nonlinear PK and difficulty of handling. ${ }^{26-28)}$ Low solubility also causes variability in the extent and rate of absorption. DJ-927 is relatively soluble in water especially in acidic condition. In the present study, oral formulation of $\left[{ }^{14} \mathrm{C}\right] \mathrm{DJ}-927$ was made as solutions in McIlvine buffer ( $\mathrm{pH} 4.0)$. The variability in the $A U C$, which is often a problem with oral chemotherapy, was small in dogs and monkeys (Table 1).

In the present study, we clarified absorption, distribution, and excretion of DJ-927 in the three kinds of species to compare the other taxanes. After a single oral administration of $\left[{ }^{14} \mathrm{C}\right] \mathrm{DJ}-927$ to mice, dogs, and monkeys, the radioactivity was rapidly absorbed, with the $C_{\max }$ occurring within $1-2 \mathrm{~h}$ after oral administration in all animals, and the elimination of radioactivity from plasma was biphasic and species-dependent (Fig. 2). The elimination half-life in dogs was much longer than those in the monkeys or mice (Table 1). In mice, the radioactivity was rapidly distributed throughout all tissues except for the central nervous system (CNS), especially to the adrenal glands, liver, pituitary glands, kidneys, lungs, and spleen (Table 2); this is similar to the pattern observed for other taxanes. ${ }^{30)}$ The radioactivity was mainly excreted in the feces in all species with less than $7 \%$ excreted in the urine as same as other taxanes (Table 3). DJ-927 highly binds to plasma proteins concentration-independently, which is also observed for other taxanes. ${ }^{29,30)}$ A slightly higher protein binding ratio was observed in mouse plasma $(98.0 \%)$ than in $\operatorname{dog}(95.0 \%)$ or monkey plasma $(92.5 \%)$ (Table 5). In short, DJ-927 has similar pharmacokinetic characteristics to both taxanes in current clinical use, which includes elimination route, high plasma protein binding, and rapid distribution to most tissues except for the CNS. ${ }^{7,9,29,30}$ However, PTX and DTX have short terminal biologic half-lives in plasma of approximately $1 \mathrm{~h}$, and they are largely inactive when administered orally. ${ }^{9}$ In contrast, DJ-927 has quite different characteristics; the pharmacokinetics results from the present study show that DJ-927 related radioactivity has a very long biologic terminal half-life after oral administration, especially in dogs and monkeys.

In conclusion, the pharmacokinetic profiles of DJ-927 were characterized after oral administration of the radiolabeled drug to the three species. The results of present study show that, in contrast to both commercially available taxanes PTX and DTX, the novel taxane DJ-927 is well absorbed in all three species and have long biological half lives especially dogs and monkeys when administered orally. DJ-927 is rapidly distributed to almost tissues except CNS but may not recognize MDR. DJ-927 is currently investigated in a Phase I clinical trial according to a global develop plan. PII clinical trials are planned in Europe and the USA. It is expected that the high oral bioavailability of this novel analog will lead to high pharmacologic efficacy.

\section{REFERENCES AND NOTES}

1) Gueritte-Voegelein F., Guenard D., Lavelle F., Le Goff M. T., Mangatal L., Potier P., J. Med. Chem., 34, 992-998 (1991).

2) Horwitz S. B., Cohen D., Rao S., Ringel I., Shen H.-J., Yang C.-P. H., J. Natl. Cancer Inst. Monogr., 15, 55-61 (1993).

3) Rowinsky E. K., Annu. Rev. Med., 48, 353-374 (1997).

4) DeMario M. D., Ratin M. J., J. Clin. Oncol., 16, 2557-2567 (1998).

5) Liu G., Franssen E., Fitch M. I., Warner E., J. Clin. Oncol., 15, 110 115 (1997).

6) Malingre M. M., Beijnen J. H., Schellens J. H. M., Investigational New Drugs, 19, 155-162 (2001).

7) Eiseman J. L., Eddington N. D., Leslie J., MacAuley C., Sentz D. L., Zuhowski M., Kujawa J. M., Young D., Egorin M. J., Cancer Chemother. Pharmacol., 34, 465-471 (1994).

8) Sparreboom A., van Asperen J., Mayer U., Schinkel A. H., Smit J. W., Meijer D. K. F., Borst P., Nooijen W. J., Beijnen J. H., van Tellingen O., Proc. Natl. Acad. Sci. U.S.A., 94, $2031-2035$ (1997).

9) Bissery M.-C., Nohynek G., Sanderink G.-J., Lavelle F., Anti-Cancer Drugs, 6, 339-368 (1995).

10) Schellens J. H. M., Malingre M. M., Kruijtzer C. M., Bardelmeijer H. A., van Tellingen O., Schinkel A. H., Beijnen J. H., Eur. J. Pharm. Sci., 12, 103-110 (2000).

11) Shirakawa K., Takara K., Tanigawara Y., Aoyama N., Kasuga M., Komada F., Sakaeda T., Okumura K., Jpn. J. Cancer Res., 90, 1380 1386 (1999).

12) Shionoya M., Jimbo T., Kitagawa M., Soga T., Tohgo A., Cancer Sci., 94, 459-466 (2003).

13) Tohgo A., Shionoya M., Iwahana M., Uesugi Y., Jimbo T., Soga T., 
Proc. Am. Assoc. Cancer Res., 43, 790 (2002).

14) Eisenhauer E. A., Vermorken J. B., Drugs, 55, 5-30 (1998).

15) Terao T., Hisanaga E., Sai Y., Tamai I., Tsuji A., J. Pharm. Pharmacol., 48, 1083-1089 (1996).

16) Van Asperen J., Van Tellingen O., Sparreboom A., Schinkel A. H., Borst P., Nooijen W. J., Beijnen J. H., Br. J. Cancer, 76, 1181-1183 (1997).

17) van Asperen J., van Tellingen O., van der Valk M. A., Rozenhart M., Beijnen J. H., Clin. Cancer Res., 4, 2293-2297 (1998).

18) Bardelmeijer H. A., Ouwehand M., Buckle T., Huisman M. T., Schellens J. H., Beijnen J. H., van Tellingen O., Cancer Res., 62, 61586164 (2002).

19) Chin K. V., Pastan I., Gottesman M. M., Adv. Cancer Res., 60, 157180 (1993).

20) Thiebaut F., Tsuruo T., Hamada H., Gottesman M. M., Pastan I., Willingham M. C., Proc. Natl. Acad. Sci. U.S.A., 84, 7735-7738 (1987).

21) Van Asperen J., Van Tellingen O., Beijnen J. H., Pharmacol. Res., 37, $429-435$ (1998).
22) Wacher V. J., Salphati L., Benet L. Z., Adv. Drug Deliv. Rev., 46, 89$102(2001)$.

23) Wacher V. J., Wu C.-Y., Benet L. Z., Mol. Carcinog., 13, 129-134 (1995).

24) Ono C., Takao A., Hayashi K., Atsumi R., Proc. Am. Assoc. Cancer Res., 43, 790 (2002).

25) Adams J. D., Flora K. P., Goldspiel B. R., Wilson J. W., Arbuck S. G., Finley R., J. Natl. Cancer Inst. Monogr., 15, 141-147 (1993).

26) Nannan Pandy V. R., Huizing M. T., ten Bokkel Huinink W. W., Vermorken J. B., Beijnen J. H., Clin. Drug Invest., 14, 418 - 427 (1997).

27) Sparreboom A., van Tellingen O., Nooijen W. J., Beijnen J. H., Cancer Res., 56, 2112-2115 (1996).

28) van Tellingen O., Huizing M. T., Panday V. R., Schellens J. H., Nooijen W. J., Beijnen J. H., Br. J. Cancer, 81, 330-335 (1999).

29) Clarke S. J., Rivory L. P., Clin. Pharmacokinet., 36, 99-114 (1999).

30) Sparreboom A., van Tellingen O., Nooijen W. J., Beijnen J. H., AntiCancer Drugs, 9, 1-17 (1998). 